\title{
Transformation of the morphometry of Lake Osieckie - largest lake in the Holy Cross region
}

\author{
Adam Choiński', Artur Zieliński², \\ ${ }^{1}$ Department of Hydrology and Water Management, Adam Mickiewicz University, Krygowskiego 10, 61-680 Poznań, \\ Poland, e-mail:choinski@amu.edu.pl \\ 2 Institute of Geography and Environmental Sciences, Jan Kochanowski University in Kielce, Uniwersytecka 7, 25-406 Kielce, \\ Poland, e-mail: artur.zielinski@ujk.kielce.pl ("corresponding author)
}

\begin{abstract}
The paper presents the analysis of the transformation of Lake Osieckie, the largest lake in the Holy Cross region until 2016. It is a valley lake that according to cartographic materials had undergone no changes in the shoreline since ca. 1938. The nearby activity of a sulphur mine required building three dikes on the lake, dividing it into four independent water bodies. The paper presents the analysis of their morphometric properties in comparison to those of the original lake. Although the basins of the new lakes are of natural origin, the currently existing four lakes can be described as quasi-natural.
\end{abstract}

Key words: fluvial lakes, Holy Cross region, morphometric properties, lake basin

\section{Introduction}

Lakes located south of the range of the Baltic glaciation, particularly those with a surface area of more than 1 ha, show sporadic occurrence (Choiński 1995). Nonetheless, in the Holy Cross region that for simplicity was herein treated as the equivalent of the Świętokrzystkie Voivodeship (Holy Cross Voivodeship), such lakes can occur more frequently (Zieliński 2010, 2013; Stachura et al. 2018). Lakes with various genesis are encountered here (aeolian, karst, and fluvial).

Such places are found e.g. on the Przedbórz Upland, in the Wierna Rzeka River catchment (Choiński and Zieliński 2020; Kirvel et al. 2021), where the objects have uniform aeolian genesis. Another, more abundant group of lakes are those of karst genesis in the northern part of the Nida Basin (Zieliński 2013; Stachura et al. 2018; Zieliński et al. 2020; Kirvel et al. 2021). A group of fluvial lakes also occurs in the Świętokrzyskie Voivodeship. They are investigated to a very low degree. Even their morphometric properties, as well as physical and chemical properties of their waters and bottom sediments are unknown. The lakes occur in the southern part of the voivodeship in river valleys. The largest lakes of the type occur in the Vistula River Plain (Solon et al. 2018). Lake Osieckie (Fig. 1) is located in the vicinity of Osiek - a town in the north-eastern part of the Staszów County. Until 2016, it had been the largest lake in terms of surface area in the Świętokrzyskie Voivodeship.

Increasingly longer periods of precipitation water deficit result in an evidently progressing process of lowering the surface water and groundwater level. As a consequence, there may be a reduction in the area, overgrowth or even disappearance of lakes (Choiński and Ptak 2008; Choiński and Kijowski 2015; Choiński and Skowron 2021). This situation triggers the necessity to pay greater attention to even small lakes and their functioning and role in the environment. Therefore, this paper aims at the expansion of knowledge regarding lakes of fluvial origin and their transformations. Lake Osieckie is a perfect example of such transformations. Investigating the lake can provide the basis for further studies on this object under strong human pressure. Areas in the vicinity of Osiek will presumably become subject to transformations similar to those in the vicinity of Grzybowo near Staszów, where sulphur was also extracted by means of the underground smelting method (Zieliński 2007; Zieliński and Wałek 2012). 
It should be emphasised that Polish scientific literature covers valley lakes in the aspect of physical and limnological research to a very low degree. The majority of publications concerning the lakes discuss issues in the scope of: hydrobiology, e.g. Gromadzińska-Graczyk (2005), Obolewski (2005), environmental engineering, e.g. Obolewski (2003), Obolewski and Glińska-Lewczuk (2006), or research with a broad scope, e.g. Glińska-Lewczuk (2005, 2009). Various studies on valley lakes in Poland have been conducted among others in the river valleys of: Warta River (Jezierska-Madziar et al. 1999), Pilica River (Penczak et al. 2000), Słupia
River (Obolewski 2006), or Łyna River (GlińskaLewczuk and Bieniek 2006). The most comprehensive analysis of limnic processes has covered the Bug River valley (Dawidek 2013). According to the author, among others: "the most seldom analysed properties resulting from the functioning of valley lakes included bathymetric properties". This statement justifies undertaking research on Lake Osieckie. In this case, next to the purely cognitive aspect of findings at a given moment, the repeatability of measurements at secified time intervals will permit the determination of the evolution of the basin of this type of lake.

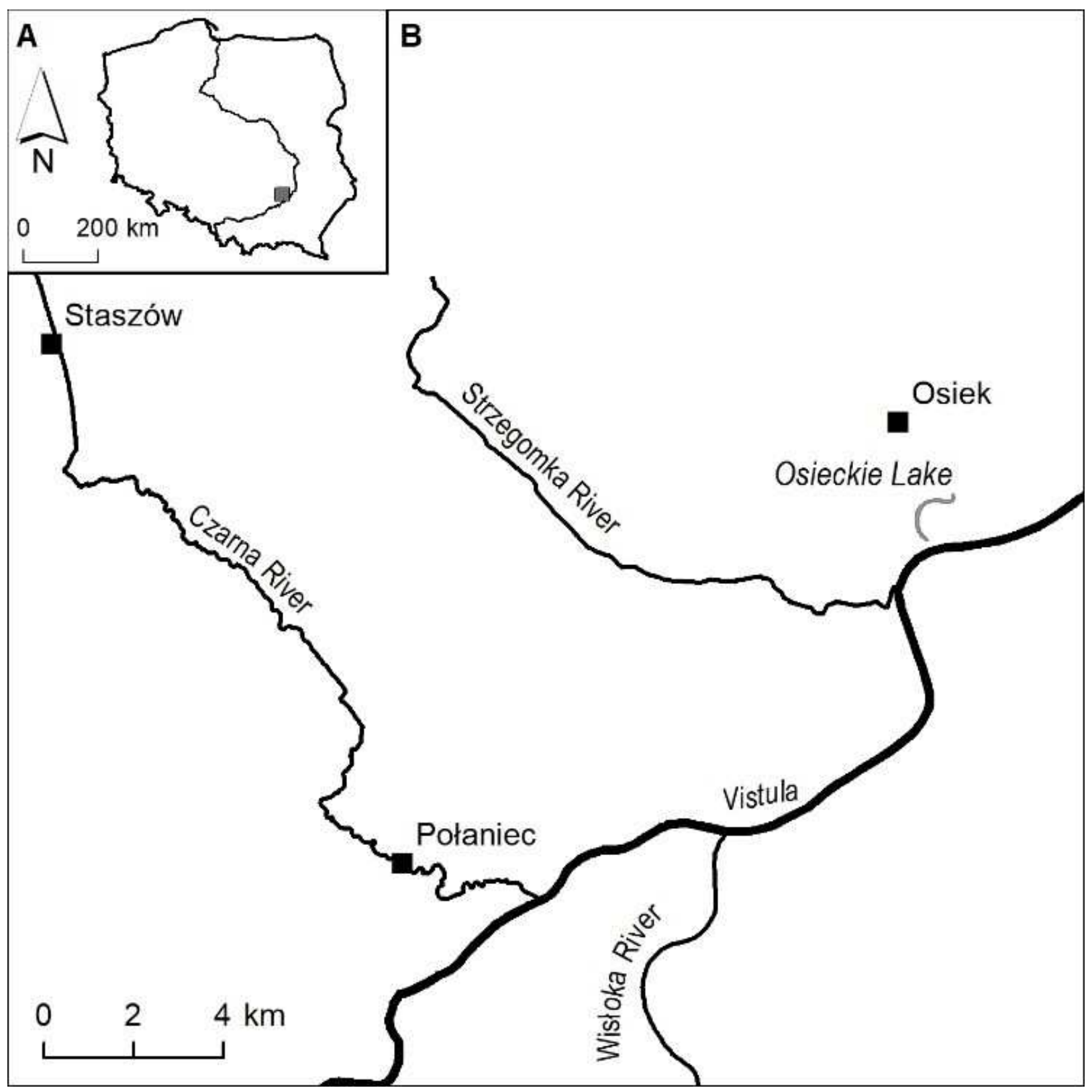

Fig. 1. Location of the study area on the background of the contour map of Poland (A) and location of Lake Osieckie (B) 


\section{Characteristics of the study object}

Lake Osieckie (Fig. 2) is a typical example of a valley lake. Therefore, the genesis of its basin and its evolution are associated with changes in the course of the river. Several names exist for this type of lakes, e.g. fluvial lake, horseshoe lake, loop lake, or oxbow lake. In the last case, when the morphological valley landform of the former river channel is not filled with water (or e.g. constitutes a wetland), it is not a lake. It should be pointed out that valley lakes also have regional names, depending on their location in the valley of a given river. Those located in the Warta River valley are called "warciska" by the local communities, those in the Bug River valley - "bużyska", and those in the Vistula River valley - "wiśliska".



Fig. 2. General view of Lake Osieckie 1 (Phot. A. Zieliński 2021)

The analysed object was created through separation of a river stretch from the main channel of the Vistula River, subject to many transformations in its history (Starkel 2001).

The analysis of the topographic map of the Kingdom of Poland, scale 1:126 000 (KGWP 1843) shows that Lake Osieckie used to be longer, with a shape resembling an elongated horseshoe. On younger and somewhat more detailed maps of the Western Russia, scale 1:100 OOO (KPL 1915, 1921), the described lake still generally has a horseshoe shape, but much less elongated. Considering the scale of the aforementioned documents and their possibilities of obtaining cartographic accuracy, however, it can only be unambiguously determined that the oxbow lake functioned at a certain distance from the channel of the Vistula River already at that time. The shape of the lake on the map was not necessarily the same as in reality.

Only topographic maps at a scale of 1:25000 (WIG 1938a, 1938b) showed that the shape and size of the lake reflected in the documents is very approximate to those presented in modern cartographic materials, e.g. topographic maps, orthophotomaps, and aerial photograph from 1961 (www.geoportal.gov.pl). Moreover, on the topographic map from 1938, the lake was called Lake Duże (Osieckie). It is also worth emphasising that the embankment separating the Vistula channel from the part of the plain with the oxbow lake was already marked on the map.

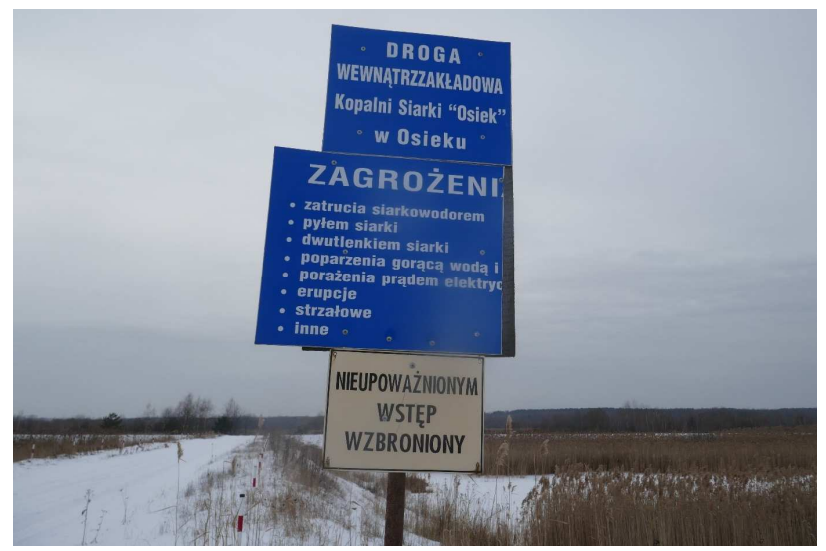

Fig. 3. One of the three dikes that divided Lake Osieckie. The visible information board enlists potential threats: poisoning by hydrogen sulphide, sulphur dust, sulphur dioxide, scalding with hot water, electric shock, eruptions, explosive and others (Phot. A. Zieliński 2021)

In the modern times, Lake Osieckie has been under strong and continuously increasing human pressure since ca. 1993 (commencement of the activity of Sulphur Mine "Osiek" in Osiek, and expansion of the area of sulphur exploitation). For the purposes of the plant, the lake was divided in 2016 through construction of three dikes across the lake, with currently functioning technical roads of the mine (Fig. 3). This resulted in the existence of four lakes that were differentiated by adding subsequent digits to the already functioning name (Fig. 4).

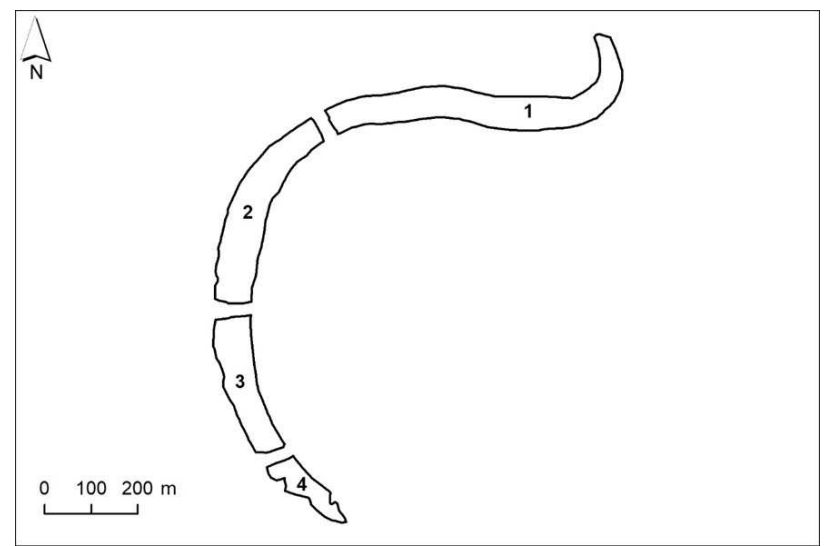

Fig. 4. Lake Osieckie after division with three dikes 1- Lake Osieckie No 1, 2 - Lake Osieckie No 2, 3 - Lake Osieckie No 3, 4 - Lake Osieckie No 4 


\section{Results and discussion}

Due to different distances of the fluvial lakes from their "parent" river, they can remain in twofold relationship with the it. The first possibility is the socalled potamophase, involving close hydraulic relations between the waters of the river and the lake. Next to water level fluctuations in both water bodies, it results in physical-chemical and biological changes in the lake waters. The other possibility is the so-called limnophase. In this case, the association of the lake with the river is negligible to the point where the lake has its own catchment determining its water supply and processes occurring in the lake. In terms of the above conditions, Lake Osieckie is in the period of limnophase. Nonetheless, in conditions of extremely high water levels in the Vistula River, the catchment of Lake Osieckie has been flooded with its waters. Such a situation is reflected in the range of flood flows of the Vistula Lagoon on hydrographic maps at a scale of 1:50 000, where it reaches the southern edge of the municipality of Osiek (GUGiK 2002, 2004).

Table 1. Surface and underwater morphometric parameters of Lake Osieckie before (whole) and after its anthropological division into four lakes (with three dikes)

\begin{tabular}{lccccc}
\hline \multirow{2}{*}{ Parameter } & \multicolumn{5}{c}{ Lake } \\
\cline { 2 - 6 } & Osieckie (whole) & Osieckie 1 & Osieckie 2 & Osieckie 3 & Osieckie 4 \\
\hline Surface area [ha] & 11.42 & 4.5 & 3.33 & 2.09 & 0.83 \\
Length [m] & 1785 & 749 & 441 & 307 & 201 \\
Maximum width [m] & 89 & 74 & 89 & 84 & 79 \\
Mean width [m] & 64 & 60 & 76 & 68 & 41 \\
Elongation index & 20.06 & 10.1 & 4.96 & 3.65 & 2.54 \\
Length of shoreline [m] & 3626 & 1567 & 1005 & 743 & 499 \\
Shoreline development & 3.02 & 2.08 & 1.55 & 1.47 & 1.56 \\
Maximum depth [m] & 2.85 & 1.85 & 1.94 & 1.73 & 2.01 \\
Mean depth [m] & 1.01 & 0.0134 & 0.0106 & 0.84 \\
Relative depth acc. Halbfass & 0.0085 & 0.39 & 0.41 & 0.012 & 0.0221 \\
Depth index & 0.35 & 4.05 & 4.16 & 0.59 & 0.42 \\
Exposure index & 11.31 & 0.011 & 0.008 & 2.05 & 0.01 \\
Compactness index & 0.01 & 49804 & 26609 & 21400 & 0.99 \\
Water volume [m] & 115047 & & & 608 \\
\hline
\end{tabular}

Table 1 includes the surface and underwater elements of Lake Osieckie (before the construction of the dikes), and four lakes that resulted from the lake's division. The presented data were marked based on the conducted field research. Depth measurements were made with a tape measure with a weight. The coordinates of the measurement sites were determined using GPS. The results were processed in accordance with the methodology presented by Choiński (2007).

Lake Osieckie has features characteristic of a lake basin, determined by its fluvial genesis. Before the interference of the sulphur mine, it was the largest lake in terms of surface area in the Swiętokrzyskie Voivodeship (11.42 ha), and one of the largest lakes of the type in Poland.

The water bodies resulting from the division of Lake Osieckie are small in terms of surface area (Figs 5-7). The largest of them is the north-eastern part of Lake Osieckie - Lake Osieckie 1. It also has the greatest maximum depth $-2.85 \mathrm{~m}$ (Fig. 5). The smallest maximum depth $(1.73 \mathrm{~m})$ is recorded for Lake Osieckie 3 (Fig. 7).
Lake Osieckie 4 has a depth somewhat larger than that of the original lake, reaching $2.01 \mathrm{~m}$ (Fig. 7).

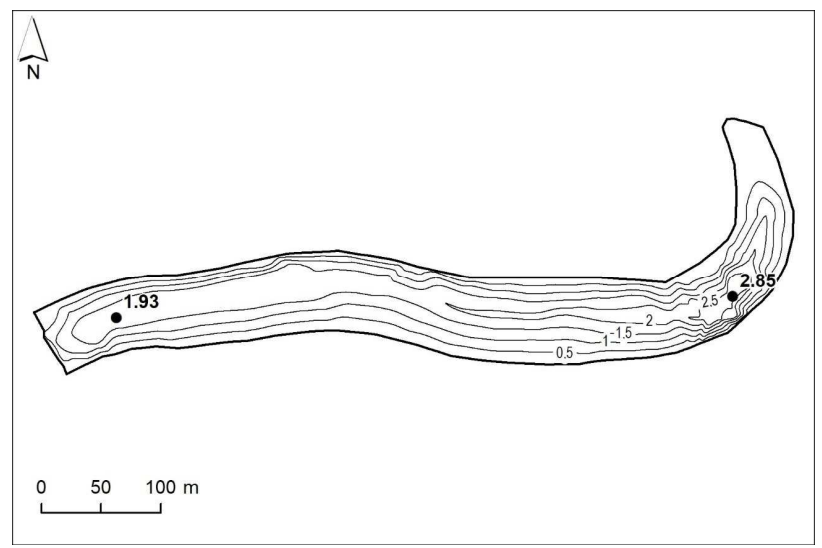

Fig. 5. Bathymetric plan of Lake Osieckie 1

It is worth emphasising that as a result of the construction of roads across Lake Osieckie, the water surface area of the four remaining parts decreased by 0.67 ha (corresponding to $5.9 \%$ of the 
water surface area). As a consequence of a decrease in the surface area, water resources decreased from $115047 \mathrm{~m}^{3}$ to $104753 \mathrm{~m}^{3}$, i.e. by approximately $9 \%$. The division of the lake also negatively affects water circulation in the lake, and the functioning of living organisms inhabiting it. The existence of the dikes and technical roads on them contributes to increased supply of anthropogenic pollutants to the lake basins.

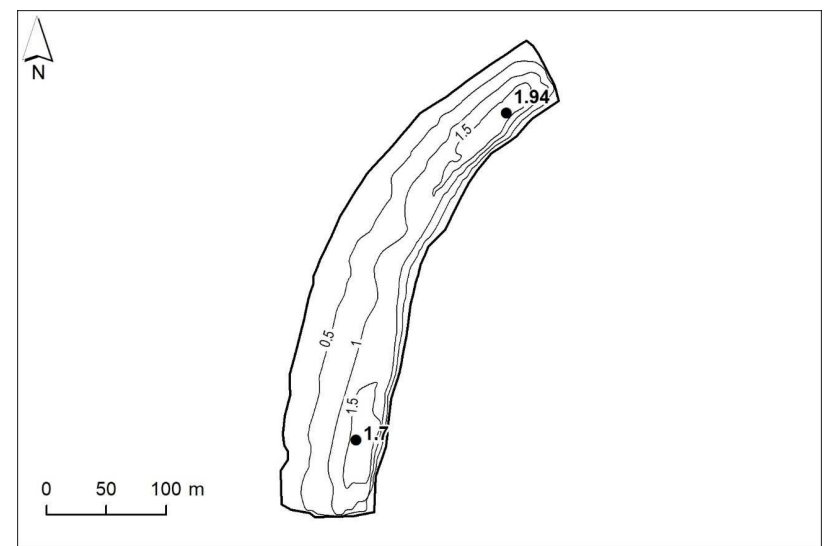

Fig. 6. Bathymetric plan of Lake Osieckie 2

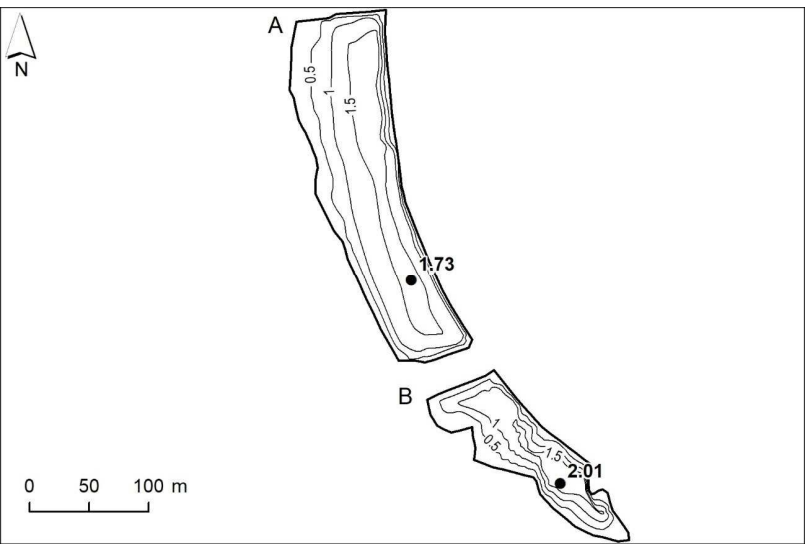

Fig. 7. Bathymetric plan of Lake Osieckie 3 (A) and Lake Osieckie 4 (B)

Moreover, considerable encroachment of reeds is observed along the shores of the lakes. The process is particularly evident in Lake Osieckie 3.

The process will further intensify due to the division of the lake resulting in an increase in the total length of the shorelines by $188 \mathrm{~m}$, i.e. by $5.2 \%$. The consequence of the division is a drastic change in the remaining morphometric properties. It is manifested the most substantially in the case of length, and the related four elongation indices the values of which are from two to eight times lower than the index determined for the original lake, reaching 20.06 . It should be pointed out that in those terms, the value placed Lake Osieckie in the top ten of all lakes in Poland. After the lake's division, properties such as maximum and mean depths, relative depths, maximum widths, mean widths, or compactness indices considerably differ from the original state due to the fact that water volumes in the new lakes were distributed relatively proportionately to new surface areas. Changes in the depth index, determining the shape of the lake basin, are intriguing. Before the division, it was 0.35, suggesting an approximately conical shape of the basin. After the division, the shapes of Lake Osieckie 1, 2, and 4 somewhat changed, i.e. they were within a range from conical to paraboloidal basins, and the basin of Lake Osieckie 3 adopted a shape between a paraboloidal and spherical. As a result of the division of the original surface area, the shoreline development and exposure indices of all the new lakes considerably decreased, suggesting a decrease in the impact of external factors (e.g. wind) on the lakes. Before the division, Lake Osieckie was a typical natural valley lake. After the division, although the origin of the basins is natural, they partially lost their original character. The new lakes can be described as quasi-natural. Moreover, the above example shows that despite a decrease in the original surface area (i.e. lake density), the number of lakes increased. Such situations occur relatively frequently in cases of division of lakes with no human interference.

\section{Conclusions}

Until the moment of intereference of Sulphur Mine "Osiek" in Osiek, Lake Osieckie was the largest lake in the Holy Cross region. As a result of strong human pressure, it was divided into four lakes. The construction of dikes led to a decrease in the water surface area in the new lakes by 0.67 ha, equivalent to $5.9 \%$.

The lakes show a relatively high variability of physical properties, as suggested by their values included in Table 1.

Although the original basin was of natural character, due to its transformation its resulting fragments are of quasi-natural character.

The small water resources of the analysed lakes may be exceptionally valuable as refugia, and therefore may become valuable research objects for biologists. The existence of the lakes emphasises the geodiversity of the described area, and substantially increases its biodiversity, as well as landscape values. Future more comprehensive research on these objects will be fully justified.

The determination of the features and properties of the lakes provides the conditions for the possibility of conducting more thorough research (among others research on the geochemistry and 
age of the bottom sediments). Undertaking such studies will permit the determination of the time when the oxbow lake lost connectivity with the Vistula River, and of the directions of transformations of the lakes.

\section{References}

Choiński A., 1995, Katalog jezior Polski. Część 3: Pojezierze Wielkopolsko-Kujawskie i jeziora na południe od linii zasięgu zlodowacenia bałtyckiego (Catalogue of Polish lakes. Part 3: Greater PolandKuyavian Lake District and lakes south of the Baltic glaciation range line), Wydaw. Nauk. UAM, Poznań, 149 pp (in Polish).

Choiński A., 2007, Limnologia fizyczna Polski (Physical limnology of Poland), Wydaw. Nauk. UAM, Poznań, 547 pp (in Polish).

Choiński A., Kijowski A., 2015, Fotolimnologia (Photolimnology), Wydaw. Nauk. UAM, Poznań, 133 pp (in Polish).

Choiński A., Ptak M., 2008, Zanikanie jezior w Wielkopolsce na tle Polski (The Wielkopolska lakes shrinkage against the background of Poland), Rocz. Glebozn. 59(2): 25-31 (in Polish, English summary).

Choiński A., Skowron R., 2021 (in press), Changes in the surface and overgrowth of lakes in Poland, Bad. Fizjogr. Pol. Zach.

Choiński A., Zieliński A., 2020, Characteristics of selected lakes with aeolian and karst genesis in the Świętokrzyski Region, Limnol. Rev. 20(2): 59-64.

Dawidek J., 2013, Procesy limniczne w strefie aktywności fluwialnej rzeki Bug pomiędzy Dorohuskiem a Włodawa (Limnic processes in the zone of fluvial activity of the Bug River between Dorohusk and Włodawa), Wydaw. UMCS, Lublin, 300 pp (in Polish).

Glińska-Lewczuk K., 2005, Oxbow lakes as biogeochemical barriers for nutrient outflow from agricultural areas, [in:] Heathwaite L, Webb B., Rosenberry D., Weaver D., Hayashi M., (eds), Dynamics and biogeochemistry of river corridors and wetlands, IAHS Publ. 294: 55-68.

Glińska-Lewczuk K., 2009, Water quality dynamics of oxbow lakes in young-glacial landscape of NE Poland in relation to their hydrological connectivity, Ecol. Eng. 35(1): 25-37.

Glińska-Lewczuk K., Bieniek A., 2006, Factors determining spatial variability of $\mathrm{Zn}$ in soils - a case study of the Middle Łyna River Valley, NE Poland, Pol. J. Environ. Stud. 15(2A): 261-268.

Gromadzińska-Graczyk H., 2005, Charakterystyka fauny epifitycznej w wybranych starorzeczach Warty [Typescript], Akademia Rolnicza, Poznań, 79-98 (in Polish).

[GUGiK] Główny Urząd Geodezji i Kartografii, 2002, Mapa Hydrograficzna Polski w skali 1:50 000, M34-55B Osiek, GEPOL, Poznań (druk Geokart-International Rzeszów).
[GUGiK] Główny Urząd Geodezji i Kartografii, 2004, Mapa Hydrograficzna Polski w skali 1:50 000, M34-55D Połaniec, ZUGiK PRYZMAT, Częstochowa (druk Geokart-International Rzeszów).

Jezierska-Madziar M., Pińskwar P., Przybył A., 1999, At attempt of quantitative and qualitative evaluation of benthofauna in Warta old River Bed, Sci. Pap. Agric. Univ. Poznan, Animal Sci. 1: 21-30.

[KGWP] Kwatermistrzostwo Generalne Wojska Polskiego, 1843, Topograficzna Karta Królestwa Polskiego (Topographic Map of the Kingdom of Poland) $126 \mathrm{~K}$ ark-29 Kol IV Sek VII Szydłów, 1:126 000.

Kirvel P., Zieliński A., Choiński A. 2021, Osobennosti malykh ozer keleckogo regiona, iugo-vostochnaia chast' tsentralnoi Pol'shi (Features of small lakes of the Kielce region, south-eastern part of central Poland), [in:]. Bogdanov S.I, Subetto D.A, Paranina A.N. (eds) Geografia: razvitie nauki i obrazovania. Sbornik statei po materialam ezhegodnoi mezhdunarodnoi nauchno-prakticheskoi konferentsii LXXIV Gertsenovskie chtenia, 21-23 aprela $2021 \mathrm{~g}$., RGPU im. A.I. Gertsena, Sankt-Peterburg: 262-265.

[KPL] Königlich Preußische Landesaufnahme, 1915, Karte des westlichen Rußlands (Map of the Western Russia) J39 Sandomierz, 1:100 000.

[KPL] Königlich Preußische Landesaufnahme, 1921, Karte des westlichen Rußlands (Map of the Western Russia) J39 Sandomierz, 1:100 000.

Obolewski K., 2003, Reakcje perifitonu na udrożnienie starorzecza rzeki Słupi (Reactions of the periphyton to clearing the oxbow lake of the Słupia river) [Dissertation], PAP w Słupsku, Słupsk, 198 pp (in Polish).

Obolewski K., 2005, Epifitic makrofauna on water soldiers (Staraiotes aloides L.) in Słupia River oxbows, Oceanol. Hydrobiol. Stud. 34(2), 37-54.

Obolewski K., 2006, Starorzecza - warty uwagi element dolin rzecznych (Oxbows - a worth of noticing element of river valleys on example of Słupia river), Infrastr. Ekol. Terenów Wiej. 4(2): 99-108 (in Polish, English summary).

Obolewski K., Glińska-Lewczuk K., 2006, Contens of heavy metals in bottom sediments of oxbow lakes and the Słupia River, Pol. J. Environ. Stud. 15 (2A): 440-444.

Penczak T., Kruk A., Koszaliński H., Kostrzewa J., Marszał L., Galicka W., Głowacki Ł., 2000, Fishes of three oxbow lakes and their parent Pilica River: 25 years later, Pol. Arch. Hydrobiol. 47(1): 115-130.

Solon J., Borzyszkowski J., Bidłasik M., Richling A., Badora K., Balon J., Brzezińska-Wójcik T., Chabudziński Ł., Dobrowolski R., Grzegorczyk I., Jodłowski M., Kistowski M., Kot R., Krąż P., Lechnio J., Macias A., Majchrowska A., Malinowska E., Migoń P., Myga-Piątek U., Nita J., Papińska E., Rodzik J., Strzyż M., Terpiłowski Sł., Ziaja W., 2018, Physico-geographical mesoregions of Poland. Verification and adjustment of boundaries on the basis of contemporary spatial data, Geogr. Pol. 91(2): 143-170. 
Stachura M., Wieczorek D., Zieliński A., 2018, An attempt at a typology of karst lakes in the Połaniec Basin (Małopolska Upland, Poland), Bull. Geogr. Phys. Geogr. 15: 63-74.

Starkel L., 2001, Historia Doliny Wisły od ostatniego zlodowacenia do dziś (Evolution of the Vistula River Valley since the last glaciation till present). Monogr. 2, IGiPZ PAN, Warszawa, 275 pp (in Polish, English summary).

[WIG] Wojskowy Instytut Geograficzny, 1938a, Mapa Szczegółowa Polski, Ark. P46-S33-G Osiek Sandomierski, 1:25 000 .

[WIG] Wojskowy Instytut Geograficzny, 1938b, Mapa Szczegółowa Polski, Ark. P47-S33-A Padew, $1: 25000$

Zieliński A., 2007, Przeobrażenia środowiska w okolicach Staszowa (Environmental transformation in the Staszów region), [in:] Zieliński A. (ed.), Przeobrażenia środowiska geograficznego $\mathrm{w}$ południowowschodniej części regionu świętokrzyskiego (The transformation of the geographical environment in the south east part of the Holy Cross region), Nauki geograficzne w badaniach regionalnych, T. VII, Instytut Geografii Akademii Świętokrzyskiej, Kielce: 87-94 (in Polish).
Zieliński A., 2010, Wstępne badania właściwości fizyczno-chemicznych wód jezior w Lasach Golejowskich koło Staszowa, Niecka Połaniecka (Preliminary studies of the physico-chemical properties of lake waters in Golejowskie Forests, Połaniecka Basin), [in:] Ciupa T., Suligowski R. (eds), Woda w badaniach geograficznych (Water in geographical studies), IG UJK, Kielce: 253-259 (in Polish, English summary).

Zieliński A., 2013, Rozwój jezior krasowych w Niecce Połanieckiej (Development of karst lakes in Połaniec Basin), Wydaw. UJK, Kielce, 186 pp (in Polish). Zieliński A., Choiński A., Machula S., Ławniczak A., Strzelczak A., 2020, Chemistry of bottom sediments from selected karst lakes in the vicinity of Staszów (Nida Basin), Limnol. Rev. 20(2): 81-87.

Zieliński A., Wałek G., 2012, Przeobrażenia środowiska geograficznego w okolicach Grzybowa (Niecka Nidziańska) w latach 1900-2001 na podstawie analizy map topograficznych (Geographical environment changes in surroundings of Grzybów (Niecka Nidziańska) in 1900-2011 on the basis of topographic maps analysis), Landform Analysis 19: 103-109 (in Polish). 